\title{
A POLÍTICA DE INCLUSÃO DOS CATADORES DE RESÍDUOS SÓLIDOS: UM ESTUDO NA CIDADE DE FORTALEZA ${ }^{1}$.
}

\section{WASTE PICKERS INCLUSION POLICIES: A CASE STUDY IN THE CITY OF FORTALEZA}

\author{
Ana Virginia Moreira Gomes ${ }^{2}$ \\ Francisco de Assis Aragão Neto ${ }^{3}$
}

\section{Resumo}

O objetivo do presente artigo é examinar se políticas de inclusão dos catadores de resíduos em sistemas de coleta e destinação final ambientalmente adequada de materiais é acompanhada de direitos que garantam a melhoria de suas condições de trabalho. Trata-se de uma pesquisa de campo, de natureza qualitativa, levada a efeito por meio de entrevistas com catadores em dois empreendimentos solidários do município de Fortaleza. As visitas realizadas indicam que, além das condições de trabalho degradantes, os trabalhadores organizados não auferem o salário mínimo mensal. A inclusão dos catadores nos sistemas de gerenciamento de resíduos por normas ambientais não thes assegura nenhum direito trabalhista. Essa política continua a possibilitar a utilização de um trabalhador vulnerável para realizar uma atividade de competência municipal. O estudo conclui que a melhoria das condições de trabalho dos catadores em um patamar de dignidade e segurança ocorrerá somente quando os sujeitos que se beneficiam da atividade desses trabalhadores se responsabilizarem por essa melhoria.

Palavras-chave: Políticas de Inclusão; Catadores de Resíduos; Organizações Coletivas; Gerenciamento de Resíduos; Aterros Sanitários.

\footnotetext{
1. Este trabalho contou com o apoio da Fundação Cearense de Apoio ao Desenvolvimento Científico e Tecnológico (FUNCAP) na elaboração de dissertação de mestrado na qual se baseia o trabalho.

2 Professora do Programa de Pós-Graduação em Direito Constitucional e do Curso de Direito da Universidade de Fortaleza. Pós-Doutorado na School of Industrial and Labor Relations da Cornell University (2007). Coordena o Núcleo de Estudos em Direito do Trabalho e Seguridade Social na Universidade de Fortaleza. E-mail: avmgomes@gmail.com

3 Mestre em Direito Constitucional pela Universidade de Fortaleza (UNIFOR). Bolsista da Fundação Cearense de Apoio ao Desenvolvimento Científico e Tecnológico (FUNCAP). E-mail: assisaragao@outlook.com
} 


\section{Abstract}

The purpose of this paper is to examine whether waste pickers inclusion policies systems are accompanied by rights to ensure the improvement of their working conditions. The paper develops a qualitative research, carried out through interviews with waste pickers in two collective organizations in the city of Fortaleza. The analysis indicate that, in addition to degrading working conditions, associated workers do not receive the minimum wage. The inclusion of waste pickers in waste management systems through environmental standards rules does not guarantee them any labour rights. This policy still allows the use of vulnerable workers to perform an activity of municipal competence. The study concludes that improving waste pickers working conditions at a level of dignity and security will occur only when the ones who benefit from the activity of these workers are hold accountable for that improvement.

Keywords: Inclusion Policies; Waste Pickers; Collective Organizations; Waste Management; Landfills. 


\section{INTRODUÇÃO}

Com o processo de urbanização e o aparecimento das primeiras epidemias em decorrência do acúmulo inadequado de lixo, a limpeza urbana tornou-se um desafio. A sociedade fundada no consumo crescente gerou a produção de resíduos e rejeitos na mesma proporção. O reconhecimento de que essa geração descontrolada afeta tanto o meio ambiente equilibrado, quanto a saúde coletiva, criou para o poder público a responsabilidade da gestão desses resíduos, além da obrigação com a limpeza urbana. No Brasil, pode-se observar um desenvolvimento significativo no conjunto de políticas que tratam da gestão de resíduos tanto no âmbito federal, quanto estadual e municipal. No entanto, argumentando a falta de recursos, grande parte das cidades ainda não efetivaram os princípios e as metas estabelecidas pelas normas ambientais, por exemplo no que concerne ao fechamento dos lixões.

Atestando essa inércia pública (e também da própria sociedade), a coleta e reciclagem de resíduos, quando realizada, ainda é feita de modo predominantemente informal por trabalhadores em condições de extrema precariedade, os catadores de resíduos. Em síntese, o poder público se esquiva de sua obrigação de gerir os resíduos e evitar a crescente degradação ambiental provocada por lixões e aterros sanitários, e admite que essa tarefa seja realizada por catadores em condições abaixo de um patamar de trabalho decente.

O trabalho na catação de resíduos tem sua origem no processo de urbanização, na década de 1950, quando foi possível identificar no Brasil um intenso fluxo migratório da população rural em direção às cidades, movimento conhecido como êxodo rural. Os retirantes rurais, atraídos pelo desenvolvimento industrial, passaram a viver nas metrópoles em uma situação de informalidade e precariedade: postos informais de trabalho, habitações precárias e insegurança alimentar.

Foi nessa conjuntura social que despontou uma classe marginalizada de trabalhadores, popularmente conhecida como "catadores de lixo" ${ }^{4}$ que, atendendo à necessidade urbana de recolhimento do material descartado, passou a executar a catação como estratégia de sobrevivência.

Desde então, os catadores continuam nas ruas das cidades brasileiras, desempenhando uma função ambiental essencial, na medida em que, além de devolverem os materiais

\footnotetext{
${ }^{4}$ A expressão "catador de lixo" é uma designação anacrônica. Atualmente, termos depreciativos estão sendo substituídos por outras denominações que remetam a uma identidade positiva do trabalhador, tais como "catador de material reciclável" ou "catador de resíduos sólidos".
} 
descartáveis à cadeia de produção, aumentando a vida útil dos aterros sanitários, adicionalmente, diminuem a utilização de recursos naturais primários pela indústria, colaborando de maneira direta com um meio ambiente equilibrado.

Os catadores exercem sua atividade de forma individual nas ruas ou lixões, ou de forma coletivas em associações e cooperativas. O trabalho nas ruas e nos lixões, em especial, expõe os catadores a condições de trabalho extremamente insalubres e perigosas. Foi a partir da década de 1980 que os catadores passaram a se associar, dividindo as sobras por meio de um sistema de economia solidária, ${ }^{5}$ no intuito de aumentar a produção, aumentar sua renda e melhorar as condições de trabalho. Isto é, o trabalho organizado coletivamente aparece como uma estratégia para a melhorias das condições de vida e de trabalho dos catadores. Essa estratégia passou a ser promovida pelo direito quando as normas ambientais sobre resíduos sólidos adotaram a política de inclusão dos catadores via suas organizações coletivas com objetivo de promover o meio ambiente sustentável e, ao mesmo tempo, reverter a circunstância socialmente exclusiva dos trabalhadores vulneráveis, inserindo-os nos sistemas de gerenciamento de resíduos. A resposta do direito, portanto, à questão dos catadores nas ruas, lixões e associação consiste na estratégia de incluí-los nos sistemas de gestão de resíduos por suas associações e cooperativas.

O objetivo deste estudo é examinar em que medida essa política de inclusão dos catadores de resíduos via suas organizações coletivas adotada pela lei ambiental brasileira é suficiente para diminuir a precariedade do trabalho do catador de resíduos.

A metodologia da pesquisa se desenvolve a partir da pesquisa bibliográfica e documental de natureza qualitativa, amparada por um trabalho de campo, levada a efeito por meio de entrevistas semiestruturadas aplicadas a dois tipos de participantes e método de observação. Inicialmente, as entrevistas foram dirigidas aos gestores representantes das diversas associações de catadores no município de Fortaleza e, em um segundo momento, a 35 indivíduos em duas organizações de catadores, sendo uma associação e uma cooperativa.

Destaca-se que, embora o roteiro das entrevistas para os dois grupos de entrevistados tenha se baseado nas categorias estudadas (condições de trabalho / saúde e segurança / ambiente de trabalho / previdência/assistência / condições de vida), as entrevistas aplicadas aos gestores focalizam também em aspectos específicos da gestão, tais como possíveis benefícios

\footnotetext{
${ }^{5}$ Economia solidária é o conjunto de atividades econômicas baseadas em práticas autogestionárias. Trata-se de uma rede de cooperação entre os trabalhadores para a prestação de serviços, baseado na igualdade entre os participantes e nas finanças solidárias.
} 
de programas sociais federais, estaduais e municipais, capacitação ou outros benefícios ao catador, controle financeiro, aspectos tributários e aspectos ligados às sobras das instituições. A análise qualitativa dos dados deu-se por meio de discussão crítica obtida pelo cruzamento de dados coletados nas entrevistas, em relação ao que se preconiza na literatura científica e ao conjunto de leis que dispõe sobre o tema em questão.

O estudo se inicia com o levantamento do arcabouço legislativo ambiental e das principais políticas públicas, com destaque para o município de Fortaleza, e análise normativa, considerando mecanismos regulatórios de garantias de direitos trabalhistas e condições de trabalho para os catadores. A seguir, o artigo estuda o caso dos catadores na cidade de Fortaleza, examinando a origem desse trabalho na cidade e analisa as condições de trabalho em duas organizações coletivas no referido município.

\section{A Política de Inclusão como Estratégia Regulatória das Organizações Coletivas de Catadores}

A política de inclusão dos catadores de resíduos nos sistemas de gerenciamento de resíduos através da cooperação entre o poder público municipal e as associações/cooperativas de catadores vem sendo considerada uma estratégia essencial para a promoção de sistemas ambientalmente sustentáveis e a diminuição da precariedade e vulnerabilidade que caracterizam o trabalho do catador. Organismos internacionais, como o Branco Mundial e o Banco Interamericano de Desenvolvimento, e organizações não-governamentais ativistas de direitos humanos, como o Women in Informal Employment: Globalizing and Organizing WIEGO, vêm apoiando o desenvolvimento dessas políticas. Trata-se de uma política de inclusão, utilizada estrategicamente como instrumento regulatório. O ordenamento jurídico brasileiro já adota a política de inclusão, porém ainda restam incertezas acerca dos efeitos dessa política para a melhoria das condições de trabalho dos catadores. A seguir, o estudo analisa como as leis e programas sociais brasileiros adotam essa estratégia no intuito de melhorar as condições de vida e trabalho dos catadores de resíduos.

\section{Análise da Legislação Federal}

A atividade de catação de resíduos surge inicialmente como uma atividade autônoma individual. Os catadores nas ruas e nos lixões constituem exemplos desse tipo de atividade. 
Somente a partir da década de 1980, no Brasil, é que se iniciou a estruturação da organização coletiva da catação, como uma estratégia possibilitar a melhorias das condições de vida e trabalho dos catadores.

Nos anos 1990, ainda sem apoio governamental, mas contando com o suporte de ONGs, foram promovidos encontros em pontos diversos do país com o objetivo de reconhecimento da atividade de catador como profissão. A incorporação de novos parceiros culminou com a formação do Movimento Nacional dos Catadores de Materiais Recicláveis (MNCR) em 2001. O movimento fortaleceu a atuação dos trabalhadores, garantindo-lhes maior protagonismo na cadeia produtiva da reciclagem. A organização coletiva também possibilitou maior reconhecimento da atividade e a criou instrumentos para que os trabalhadores pudessem influenciar a elaboração de políticas públicas.

Em 2002, os catadores conquistaram o reconhecimento como categoria profissional, oficializada na Classificação Brasileira de Ocupações (CBO), sendo identificados como "catadores de materiais recicláveis". Consoante a descrição das atividades, os trabalhadores do setor de resíduos "catam, selecionam e vendem materiais recicláveis como papel, papelão e vidro, bem como materiais ferrosos e não ferrosos e outros materiais reaproveitáveis". O próximo passa seria a inclusão dessa atividade nos sistemas de gerenciamento de resíduos.

O Quadro 1 mostra a evolução legal acerca do desenvolvimento de uma política federal de gerenciamento de resíduos sólidos no Brasil.

Quadro 1: Legislação Ambiental Federal

\begin{tabular}{|c|c|}
\hline $\begin{array}{l}\text { Legislação em } \\
\text { sentido estrito }\end{array}$ & Assunto \\
\hline Lei $n^{\circ} 5.318 / 67$ & Institui a Política Nacional de Saneamento \\
\hline Lei $n^{\circ} 6.938 / 81$ & Dispõe acerca da Política Nacional do Meio Ambiente. \\
\hline Lei $n^{\circ} 7.347 / 85$ & $\begin{array}{l}\text { Trata da Ação Civil Pública de responsabilidade por danos causados ao Meio } \\
\qquad \text { Ambiente. }\end{array}$ \\
\hline Lei $n^{\circ} 7.797 / 89$ & Institui o Fundo Nacional do Meio Ambiente. \\
\hline Lei $n^{\circ} 7.802 / 89$ & $\begin{array}{l}\text { Dispõe sobre a pesquisa, a produção, a embalagem, a rotulagem, o } \\
\text { transporte, o armazenamento, a destinação final dos resíduos e embalagens } \\
\text { e a fiscalização de agrotóxicos e seus componentes. }\end{array}$ \\
\hline Lei $n^{\circ} 9.008 / 95$ & Estabelece o Fundo dos Direitos Difusos. \\
\hline
\end{tabular}




\begin{tabular}{|c|c|}
\hline Lei $n^{\circ} 9.605 / 98$ & $\begin{array}{l}\text { Dispõe acerca das sanções penais e administrativas advindas de condutas e } \\
\text { atividades lesivas ao meio ambiente. }\end{array}$ \\
\hline Lei $n^{\circ} 10.257 / 01$ & Institui o Estatuto das Cidades. \\
\hline Lei $n^{\circ} 11.445 / 07$ & $\begin{array}{l}\text { Inclui como hipótese de dispensa licitatória a contratação direta de } \\
\text { organizações coletivas de catadores pelo Poder Público. }\end{array}$ \\
\hline Lei $n^{\circ} 12.305 / 10$ & Institui a Política Nacional de Resíduos Sólidos \\
\hline $\begin{array}{l}\text { Decretos } \\
\text { Federais }\end{array}$ & Assunto \\
\hline $\begin{array}{l}\text { Decreto } n^{\circ} \\
50.877 / 61\end{array}$ & $\begin{array}{l}\text { Dispõe sobre o lançamento de resíduos tóxicos nas águas interiores ou } \\
\text { litorâneas do país. }\end{array}$ \\
\hline $\begin{array}{l}\text { Decreto } n^{\circ} \\
76.389 / 75\end{array}$ & Trata do controle da poluição industrial. \\
\hline $\begin{array}{l}\text { Decreto } n^{\circ} \\
86.028 / 81\end{array}$ & Institui a Semana Nacional do Meio Ambiente. \\
\hline $\begin{array}{l}\text { Decreto } n^{\circ} \\
875 / 93\end{array}$ & $\begin{array}{l}\text { Promulga o texto da Convenção sobre o controle de movimentos } \\
\text { transfronteiriços de resíduos sólidos e seus depósitos. }\end{array}$ \\
\hline $\begin{array}{l}\text { Decreto } \mathrm{n}^{\circ} \\
1.306 / 94\end{array}$ & Regulamenta o Fundo de Direitos Difusos. \\
\hline $\begin{array}{l}\text { Decreto } \mathrm{n}^{\circ} \\
3.179 / 99\end{array}$ & $\begin{array}{l}\text { Regulamenta as sanções administrativas aplicáveis às condutas e atividades } \\
\qquad \text { lesivas ao ambiente. }\end{array}$ \\
\hline $\begin{array}{l}\text { Decreto } n^{\circ} \\
5.940 / 06\end{array}$ & $\begin{array}{l}\text { Institui a separação de resíduos sólidos na fonte pelo Poder Público Federal e } \\
\text { sua destinação às associações e cooperativas de catadores. }\end{array}$ \\
\hline $\begin{array}{l}\text { Decreto } n^{\circ} \\
7.217 / 10\end{array}$ & $\begin{array}{c}\text { Regulamenta a Lei } n^{\circ} 11.445 / 07 \text { que traça diretrizes nacionais para o } \\
\text { saneamento básico. }\end{array}$ \\
\hline $\begin{array}{l}\text { Decreto } n^{\circ} \\
7.404 / 10\end{array}$ & Regulamenta a Lei que institui a Política Nacional de Resíduos Sólidos. \\
\hline $\begin{array}{l}\text { Decreto } \mathrm{n}^{\circ} \\
7.405 / 10\end{array}$ & $\begin{array}{l}\text { Institui o programa Pró-catador e o Comitê Interministerial para inclusão } \\
\text { Social e Econômica dos Catadores. }\end{array}$ \\
\hline
\end{tabular}
Fonte: Adaptado de Sanetal (2012, p. 234).

A primeira inovação no sentido da inclusão dos catadores veio com o Decreto $\mathrm{n}^{\circ}$ 5.940/06 que instituiu a separação dos recicláveis descartados pela Administração Pública 
federal direta e indireta, destinando-os às associações e cooperativas de catadores. Outro avanço importante relacionado ao reconhecimento dos catadores foi a Lei $n^{\circ} 11.445 / 2007$, que alterou a Lei $n^{\circ}$ 8.666/93, ao dispensar a contratação pelo Poder Público de organizações coletivas de catadores de processo licitatório.

A mobilização do MNCR e a atuação governamental foram fundamentais para a promulgação da Lei no 12.305/10 que instituiu a Política Nacional de Resíduos Sólidos ${ }^{6}$, dispondo sobre princípios, objetivos, instrumentos e diretrizes relativos ao gerenciamento de resíduos sólidos. A Lei no 12.305/10 representa um marco regulatório quanto à legislação ambiental e para o reconhecimento da organização coletiva e do papel dos catadores na coleta e reciclagem dos resíduos ao adotar a estratégia de inclusão social dos catadores de resíduos no sistema delineado pela PNRS, conforme destacado no Quadro 2:

\section{Quadro 2: Análise da Política de Inclusão}

\begin{tabular}{|c|c|}
\hline $\begin{array}{l}\text { Artigo } 3^{\circ}, \\
\text { inciso XVII }\end{array}$ & $\begin{array}{l}\text { Define a responsabilidade compartilhada pelo ciclo de vida dos produtos entre } \\
\text { fabricantes, importadores, distribuidores e comerciantes, dos consumidores e } \\
\text { dos titulares dos serviços públicos de limpeza urbana e de manejo dos resíduos } \\
\text { sólidos - os municípios. }\end{array}$ \\
\hline $\begin{array}{l}\text { Artigo } 7^{\circ} \\
\text { inciso XII }\end{array}$ & $\begin{array}{l}\text { Dispõe no, que dentre seus objetivos está a "integração dos catadores de } \\
\text { materiais reutilizáveis e recicláveis nas ações que envolvam a responsabilidade } \\
\text { compartilhada pelo ciclo de vida dos produtos". }\end{array}$ \\
\hline Art. $8^{\circ}$, IV & $\begin{array}{l}\text { Define como instrumento da PNRS "o incentivo à criação e ao desenvolvimento } \\
\text { de cooperativas ou de outras formas de associação de catadores de materiais } \\
\text { reutilizáveis e recicláveis". }\end{array}$ \\
\hline $\begin{array}{l}\text { Artigo 15, } \\
\text { inciso V }\end{array}$ & $\begin{array}{l}\text { Estipula como conteúdo mínimo do Plano Nacional de Resíduos Sólidos a } \\
\text { inclusão e a emancipação econômica dos catadores. }\end{array}$ \\
\hline $\begin{array}{l}\text { Artigo } 18, \S \\
10 \text {, inciso II }\end{array}$ & $\begin{array}{l}\text { Estabelece, no que concerne aos Planos Municipais de Gestão Integrada de } \\
\text { Resíduos Sólidos, priorizados no acesso aos recursos da União os municípios } \\
\text { que "implantarem a coleta seletiva com a participação de cooperativas ou } \\
\text { outras formas de associação de catadores de materiais reutilizáveis e recicláveis } \\
\text { formadas por pessoas físicas de baixa renda". }\end{array}$ \\
\hline
\end{tabular}

\footnotetext{
${ }^{6}$ Importante destacar que a PNRS integra a Política Nacional do Meio Ambiente e se articula com a Política Nacional de Educação Ambiental e com a Política Federal de Saneamento Básico.
} 


\begin{tabular}{|c|c|}
\hline $\begin{array}{l}\text { Art. } 18, \S 1^{\circ} \\
\qquad \begin{array}{l}\text { da Lei } \\
12.305 / 10\end{array}\end{array}$ & $\begin{array}{l}\text { Na elaboração dos Planos Municipais de Resíduos Sólidos terão prioridade a } \\
\text { recursos federais os municípios que investirem em coleta seletiva contando } \\
\text { com a participação de cooperativas e associações de catadores. }\end{array}$ \\
\hline $\begin{array}{l}\text { Artigo 19, } \\
\text { inciso XXI }\end{array}$ & $\begin{array}{l}\text { Dispõe como conteúdo mínimo dos Planos Municipais de Gestão Integrada de } \\
\text { Resíduos Sólidos "programas e ações para a participação dos grupos } \\
\text { interessados, em especial das cooperativas ou outras formas de associação de } \\
\text { catadores de materiais reutilizáveis e recicláveis formadas por pessoas físicas } \\
\text { de baixa renda, se houver". }\end{array}$ \\
\hline Artigo 36, § & $\begin{array}{l}\text { No que concerne à responsabilidade compartilhada, dispõe sobre a prioridade a } \\
\text { ser dada pelo titular dos serviços públicos de limpeza urbana e de manejo de } \\
\text { resíduos sólidos à "organização e o funcionamento de cooperativas ou de } \\
\text { outras formas de associação de catadores de materiais reutilizáveis e recicláveis } \\
\text { formadas por pessoas físicas de baixa renda, bem como sua contratação". }\end{array}$ \\
\hline $\begin{array}{l}\text { Artigo 42, } \\
\text { inciso III }\end{array}$ & $\begin{array}{l}\text { Estabelece a prioridade na instituição de medidas indutoras e linhas de } \\
\text { financiamento às iniciativas de "implantação de infraestrutura física e aquisição } \\
\text { de equipamentos para cooperativas ou outras formas de associação de } \\
\text { catadores de materiais reutilizáveis e recicláveis formadas por pessoas físicas } \\
\text { de baixa renda". }\end{array}$ \\
\hline $\begin{array}{c}\text { Artigo 44, } \\
\text { inciso II }\end{array}$ & $\begin{array}{l}\text { Dispõe sobre a possibilidade de concessão de incentivos fiscais, financeiros ou } \\
\text { creditícios a "projetos relacionados à responsabilidade pelo ciclo de vida dos } \\
\text { produtos, prioritariamente em parceria com cooperativas ou outras formas de } \\
\text { associação de catadores de materiais reutilizáveis e recicláveis formadas por } \\
\text { pessoas físicas de baixa renda". }\end{array}$ \\
\hline
\end{tabular}

É precisamente na integração dos catadores na responsabilidade compartilhada pelo ciclo de vida dos produtos que se manifesta a relevância da Lei $n^{\circ} 12.305 / 10$. Dito de uma outra forma, os trabalhadores se tornam sujeitos ativos para se alcançar os objetivos da PNRS e o cumprimento das obrigações ligadas à gestão de resíduos sólidos juntamente com fabricantes, importadores, distribuidores, comerciantes, consumidores e titulares do serviços públicos de limpeza urbana; podendo, inclusive, os Entes Federados, no âmbito de suas competências, instituir normas que permitam a concessão de benefícios creditícios, financeiros e fiscais 
voltados para projetos cujo teor se relacione à responsabilidade compartilhada dos produtos em parceria com a organização coletiva de catadores. ${ }^{7}$

No que diz respeito ao repasse de recursos por parte da União aos Municípios e ao Distrito Federal para investimento em limpeza urbana e manejo de resíduos, a Lei $n^{\circ}$ 12.305/10 estabelece como condição a elaboração de Planos Municipais de Gestão integrada de Resíduos Sólidos cuja prioridade de investimento se destina à implantação da coleta seletiva com a participação dos empreendimentos solidários dos trabalhadores. Ademais, a lei determina, como conteúdo mínimo do referido Plano Municipal, programas e ações para participação de grupos interessados, sobretudo de catadores, compostas por pessoas físicas de baixa renda.

A lei obriga ainda a adoção da logística reversa ${ }^{8}$, independentemente do serviço público de limpeza urbana, aos fabricantes; importadores; distribuidores; e os comerciantes de produtos eletroeletrônicos e seus componentes, agrotóxico, pilha, baterias, pneus, óleos lubrificantes, lâmpadas fluorescentes de vapor de sódio e mercúrio e de luz mista. ${ }^{9}$ Para cumprirem a determinação legal, os obrigados a realizar a logística reversa podem atuar em parceria com associações e cooperativas de catadores. ${ }^{10}$

Um dos instrumentos econômicos dos quais o poder público pode se valer para a consecução do ideal da PNRS é a implantação de cooperativas e associações de catadores, bem como a compra dos equipamentos necessários para o desenvolvimento de seus trabalhos, demonstrando, mais uma vez, a escolha do legislador em priorizar a participação dos profissionais vulneráveis na gestão integrada dos resíduos. ${ }^{11}$

Após a promulgação da Lei n 12.305/10, em 23 de dezembro 2010, com o objetivo de regulamentar a matéria, o Poder Executivo Federal editou o Decreto $n^{\circ} 7.404 / 10$. Esse ato normativo defere capítulo próprio para regular a atuação prioritária do catador na atividade de coleta seletiva e de logística reversa ${ }^{12}$, demostrando a sua posição de destaque na PNRS. 0 decreto trouxe um indispensável instrumento econômico, indutor de uma destinação adequada aos resíduos sólidos, qual seja: o pagamento por serviços ambientais (PSA). O PSA destina-se a cooperativas ou outras formas de associação do trabalho dos catadores, sendo um vetor de

\footnotetext{
${ }^{7}$ Art. 44, II da Lei $n^{\circ} 12.305 / 10$.

${ }^{8}$ Art. $3^{\circ}$ da Lei 12.305/10: Logística reversa é "um conjunto de ações, procedimentos e meios destinados a viabilizar a coleta e a restituição dos resíduos sólidos ao setor empresarial, para reaproveitamento, em seu ciclo ou em outros ciclos produtivos, ou outra destinação final ambientalmente adequada".

${ }^{9}$ Art. 33 da Lei 12.305/10.

${ }^{10}$ Art. 33, $\S 3^{\circ}$, III da Lei $n^{\circ} 12.305 / 10$.

${ }^{11}$ Art. 42, III da Lei $n^{\circ} 12.305 / 10$.

${ }^{12}$ Art. $11 \mathrm{c} / \mathrm{c}$ Art. $18, \S 1^{\circ}$ do Decreto Federal n ${ }^{\circ} 7.404 / 10$.
} 
formação das organizações coletivas. ${ }^{13}$ O Decreto $n^{0}$ 7.217/10 prevê que associações e cooperativas de catadores que executam a coleta, o processamento e a comercialização dos resíduos sólidos devem ser reconhecidas como prestadoras de serviço público, demonstrando o interesse do Estado no trabalho de gerenciamento de resíduos compartilhado com o grupo vulnerável. ${ }^{14}$

O Decreto $n^{\circ} 7.404 / 10$ determina que os empreendimentos dos catadores poderão participar da elaboração de acordos setoriais ${ }^{15}$ para a implantação do sistema de logística reversa. Tais acordos devem prever como condições mínimas a possibilidade de contratação dos trabalhadores organizados. Além disso, as propostas dos acordos setoriais serão objeto de consulta pública a ser realizada pelo Ministério do Meio Ambiente que, em avaliação, deverá atentar-se à capacidade de inclusão social de cooperativas e associações daqueles trabalhadores como critério mínimo de aceitabilidade. ${ }^{16}$

Resta claro, no entanto, que a legislação federal ambiental trata da organização coletiva de catadores, de maneira geral sob uma perspectiva inclusiva, porém, sem assegurar de forma específica condições de trabalho decente para essa atividade. São esses trabalhadores extremamente vulneráveis - que por sua organização coletiva devem reestruturar o trabalho em condições minimamente dignas. Não se pode negar o avanço que a PNRS trouxe ao meio ambiente, não tendo o intuito imediato de conferir direitos aos catadores, embora dependa em grande parte de sua atividade para atingir os objetivos de uma adequada destinação dos resíduos.

\section{Análise da Legislação Ambiental do Ceará}

Embora a atuação do Ceará no que diz respeito à promulgação de leis ambientais e decretos no que concerne ao gerenciamento de resíduos sólidos ainda pareça insuficiente, é preciso reconhecer alguns avanços alcançados para diminuir a geração de resíduos e desenvolver técnicas para reduzir o impacto ambiental. O Quadro 3 apresenta os principais

\footnotetext{
${ }^{13} \mathrm{O}$ pagamento por serviços ambientais (PSA), inicialmente utilizado para questões relacionadas ao uso do solo, foi estendido aos serviços urbanos ligados a assuntos ambientais. Trata-se de uma compensação financeira direcionada aos catadores por coletar resíduos e contribuir para o retorno dos materiais à cadeia produtiva.

${ }^{14}$ Art. $2^{\circ}, \S 3^{\circ}$ do Decreto $n^{\circ} 7.217 / 10$.

${ }^{15} \mathrm{Art}$. 30, I da Lei n 12.305/10: Acordo setorial: ato de natureza contratual firmado entre o poder público e fabricantes, importadores, distribuidores ou comerciantes, tendo em vista a implantação da responsabilidade compartilhada pelo ciclo de vida do produto.

${ }^{16}$ Art. 20, $\S 3^{\circ}$ e Art. 23, IV c/c Art. 28, VI, Lei n 12.305/10.
} 
instrumentos legislativos estaduais ligados ao meio ambiente para a análise da promoção do trabalho coletivo do catador.

Quadro 3: Legislação Ambiental do Estado do Ceará

\begin{tabular}{|c|c|}
\hline $\begin{array}{l}\text { Leis em sentido } \\
\text { estrito }\end{array}$ & Assunto \\
\hline $\begin{array}{l}\text { Lei } \mathrm{n}^{\circ} \\
11.411 / 87\end{array}$ & $\begin{array}{l}\text { Trata da Política Estadual de Meio Ambiente, além de) instituir o Conselho } \\
\text { Estadual de Meio Ambiente (COEMA) e a Superintendência Estadual do Meio } \\
\text { Ambiente (SEMACE). }\end{array}$ \\
\hline $\begin{array}{l}\text { Lei } n^{\circ} \\
11.423 / 88\end{array}$ & Fixa a proibição de depósito de rejeitos radioativos no Estado. \\
\hline $\begin{array}{l}\text { Lei } n^{\circ} \\
12.225 / 93\end{array}$ & $\begin{array}{l}\text { Reconhece a coleta seletiva e a reciclagem como atividade de interesse do } \\
\text { estado. }\end{array}$ \\
\hline $\begin{array}{l}\text { Lei } n^{\circ} \\
12.944 / 99\end{array}$ & $\begin{array}{l}\text { Estabelece o descarte ambientalmente adequado de pilhas de até } 9 \text { volts e } \\
\text { baterias de celulares, bem como artefatos formados por metais pesados. }\end{array}$ \\
\hline $\begin{array}{l}\text { Lei } n^{\circ} 13.103 / 01 \\
\text { (revogada) }\end{array}$ & Dispõe sobre a Política Estadual de Resíduos Sólidos do Ceará. \\
\hline $\begin{array}{l}\text { Lei } n^{\circ} \\
13.304 / 03\end{array}$ & Institui o "Selo Município Verde" e o "Prêmio Sensibilidade ambiental". \\
\hline $\begin{array}{l}\text { Lei } n^{\circ} \\
14.198 / 08\end{array}$ & Estabelece a Política Estadual de combate e prevenção à desertificação. \\
\hline $\begin{array}{l}\text { Lei } n^{\circ} \\
14.401 / 09\end{array}$ & $\begin{array}{l}\text { Institui o dia } 6 \text { de junho de cada ano como comemoração ao agente } \\
\text { ambiental. }\end{array}$ \\
\hline $\begin{array}{l}\text { Lei } n^{\circ} \\
14.892 / 11\end{array}$ & Dispõe sobre a Política Estadual de Educação Ambiental do Ceará. \\
\hline $\begin{array}{l}\text { Lei } n^{\circ} \\
15.086 / 11\end{array}$ & $\begin{array}{l}\text { Institui o selo verde para certificar produtos compostos de material } \\
\text { reciclado. }\end{array}$ \\
\hline $\begin{array}{l}\text { Lei } n^{\circ} \\
15.093 / 11\end{array}$ & $\begin{array}{l}\text { Estabelece o Cadastro técnico de Atividades potencialmente poluidoras ou } \\
\text { utilizadoras de recursos ambientais, além de instituir taxas de controle e } \\
\text { fiscalização ambiental. }\end{array}$ \\
\hline Lei $16032 / 16$ & Dispõe sobre a Política Estadual de Resíduos Sólidos do Ceará. \\
\hline Decretos & Assuntos \\
\hline
\end{tabular}




\begin{tabular}{|c|c|}
\hline Estaduais & \\
\hline Decreto $n^{\circ}$ & Regula a Política Estadual de Resíduos Sólidos. \\
$26.604 / 02$ & Dispõe acerca da entrega de percentagem do ICMS ao município que \\
\hline Decreto $n^{\circ}$ & apresente boa gestão ambiental. \\
$29.306 / 08$ & For \\
\hline
\end{tabular}
Fonte: Adaptado de Sanetal (2012, p. 244).

A Lei $n^{\circ} 12.225 / 93$ conferiu à coleta seletiva e à reciclagem a qualidade de atividades ecológicas de relevância social e de interesse público estadual, eficientes na redução de custos e danos ambientais. O dispositivo legal compreende ações estatais em relação à destinação do lixo urbano em cooperação com os municípios cujas diretrizes se baseiam no aumento do acesso ao serviço de coleta de lixo no estado, bem como na definição de áreas e procedimentos para armazenamento de resíduos, determinando igualmente o controle estatal dos aterros sanitários e o incentivo às empresas privadas para a reciclagem, além de estabelecer políticas educativas à sociedade em relação à coleta e à reciclagem dos resíduos. ${ }^{17}$

As medidas de combate à degradação ambiental no Estado também envolvem a preocupação com o descarte adequado de resíduos, motivo pelo qual a Lei $n^{\circ}$ 12.944/99 regulamentou a disposição final de pilhas de até 9 volts, baterias de celulares e artefatos que contenham metais pesados para impedir a incineração ou o descarte em depósitos públicos e em lixos domésticos ou comerciais.

Em 2011, foi promulgada a Lei n 15.093/11 que instituiu o cadastro técnico estadual de atividades potencialmente poluidoras, classificando a destinação de resíduos urbanos como grau médio. Outrossim, a referida lei estadual criou a taxa de controle ambiental, conferindo à SEMACE poder fiscalizatório a ser exercido sobre aqueles que realizam atividade potencialmente deletéria.

Relevância também deve ser dada à Lei $n^{\circ}$ 15.086/11 que instituiu o selo verde para identificação de empresários individuais ou sociedades empresárias os quais no processo de fabricação utilizam produtos compostos por materiais recicláveis com escopo de conferir-Ihes incentivos fiscais, fomentando a sustentabilidade ambiental no Estado.

Em 20 de junho de 2016, foi promulgada a Lei 16032 que institui Política Estadual de Resíduos Sólidos do Ceará, revogando a Lei n 13.103/01, que definia a política estadual

${ }^{17}$ Art. $2^{\circ}$, Lei $n^{\circ} 12.225 / 93$. 
anterior sem expressar qualquer vínculo entre o trabalho do catador e o sistema de gerenciamento de resíduos. A Lei 16032/16 dispõe sobre as diretrizes para a gestão integrada e o gerenciamento ambientalmente adequado dos resíduos sólidos, que considera também a dimensão social do manejo dos resíduos.

A Política Estadual traz como princípios "a responsabilidade compartilhada pelo ciclo de vida dos produtos" e "o reconhecimento do resíduo sólido reutilizável e reciclável como um bem econômico e de valor social, gerador de trabalho e renda e promotor de cidadania" (Artigo $\left.6^{\circ}\right)$. Estabelece, nesse sentido, como objetivos a promoção de aquisições e contratações governamentais que: promovam a "integração dos catadores de materiais reutilizáveis e recicláveis nas ações que envolvam a responsabilidade compartilhada pelo ciclo de vida dos produtos" e estimulem "a organização, por meio de incentivos financeiros, dos catadores e catadoras em cooperativas e associações, de modo a contribuir para o seu desenvolvimento econômico e inclusão social" (Artigo $7^{\circ}$ ).

A Política Estadual define, ainda, como uma das metas a serem previstas no Plano Estadual de Resíduos Sólidos ações para a "emancipação econômica de catadores de materiais reutilizáveis e recicláveis". Por fim, no que concerne aos Planos Municipais de Gestão Integrada de Resíduos, a Política Estadual estabelece que terão prioridade no recebimento de recursos destinados à limpeza pública e manejo de resíduos os municípios que "implantarem a coleta seletiva com a participação de cooperativas ou outras formas de associação de catadores de materiais reutilizáveis e recicláveis, formadas por pessoas físicas de baixa renda" (Artigo 18).

Como forma de possibilitar a formação e sobrevivência das organizações de catadores, a Política Estadual prevê a possibilidade de financiamento de ações voltadas à "implantação de infraestrutura física e aquisição de equipamentos para cooperativas ou outras formas de associação de catadores de materiais reutilizáveis e recicláveis formadas por pessoas físicas de baixa renda" (Artigo 43), além da possibilidade de concessão pelo estado de incentivos fiscais, financeiros ou creditícios (Artigo 44). A Política estabelece ainda o programa "Bolsa Catador", uma espécie de pagamento por serviços ambientais, que conforme a Lei 16032/16 consiste "em incentivos financeiros periódicos prestados pelo Estado às cooperativas e associações de catadores com o objetivo de incentivar as atividades de reutilização, reciclagem e tratamento dos resíduos sólidos, bem como promover a inclusão social da categoria" (Artigo 65). ${ }^{18}$

18 O Plano depende ainda de decreto estadual que regule o valor, periodicidade e condiçoes de pagamento da bolsa. 
A Política Estadual de Resíduos Sólidos no Ceará segue, portanto, as diretrizes da Política Nacional de Resíduos Sólidos, adotando a política de inclusão dos catadores via sua organização coletiva - cooperativas ou associações -, possibilitando a adoção de incentivos econômicos a essas organizações, inclusive com o pagamento da bolsa catador; porém sem estabelecer diretamente condições mínimas para o trabalho dos catadores e tampouco normas de responsabilização do poder público no caso de formas de trabalho abaixo de um patamar de dignidade, como todos os dias no trabalho em lixões e de catação nas ruas.

\section{Análise da Legislação Ambiental de Fortaleza}

O município de Fortaleza tem uma ampla legislação que dispõe sobre a proteção dos ecossistemas, conforme disposta no Quadro 4:

Quadro 4: Legislação Ambiental do Município de Fortaleza

\begin{tabular}{|c|c|}
\hline $\begin{array}{c}\text { Leis em sentido } \\
\text { estrito }\end{array}$ & Assunto \\
\hline Lei $n^{\circ} 4.384 / 74$ & Institui a seção de Engenharia Sanitária da Secretaria Municipal de \\
Saúde.
\end{tabular}




\begin{tabular}{|c|c|}
\hline $\begin{array}{l}\text { Lei Complementar } \\
\text { 062/09 }\end{array}$ & Institui o Plano Diretor Participativo de Fortaleza. \\
\hline Lei $n^{\circ} 8.408 / 99$ & $\begin{array}{l}\text { Fixa normas de responsabilidade sobre manipulação de resíduos } \\
\text { produzido em grandes quantidades em Fortaleza. }\end{array}$ \\
\hline Lei $\mathrm{n}^{\circ} 8.621 / 02$ & Institui o Sistema Municipal de Limpeza Urbana. \\
\hline Lei $n^{\circ} 9.357 / 08$ & $\begin{array}{l}\text { Refere-se à obrigação de implantar coleta seletiva nas praças de } \\
\text { alimentação de shoppings e supermercados em Fortaleza }\end{array}$ \\
\hline Lei $n^{\circ} 9.536 / 09$ & Trata da reciclagem e da destinação final de eletrônicos no município \\
\hline Lei $n^{\circ} 9.927 / 12$ & $\begin{array}{l}\text { Trata da responsabilidade das indústrias farmacêuticas e das empresas } \\
\text { de distribuição de medicamentos sobre a destinação ambientalmente } \\
\text { adequada de medicamentos vencidos. }\end{array}$ \\
\hline Lei $n^{\circ} 9.947 / 12$ & $\begin{array}{c}\text { Regulamenta o tratamento e a reciclagem de óleos e gorduras de } \\
\text { origem vegetal ou animal e uso culinário. }\end{array}$ \\
\hline Lei $n^{\circ} 10.006 / 13$ & Institui a Semana Municipal de Reciclagem do Lixo. \\
\hline Lei $n^{\circ} 10.183 / 14$ & $\begin{array}{l}\text { Institui o selo "Empresa amiga do Meio Ambiente" em Fortaleza, } \\
\text { conferindo certificado de gentileza ambiental. }\end{array}$ \\
\hline Lei $n^{\circ} 10.190 / 14$ & $\begin{array}{l}\text { Dispõe sobre a coleta, o recolhimento e o destino final de embalagens } \\
\text { plásticas vazias de óleos lubrificantes. }\end{array}$ \\
\hline Lei $n^{\circ} 10.204 / 14$ & $\begin{array}{l}\text { Trata da colocação de adesivos educativos sobre a proteção ambiental } \\
\qquad \text { do município. }\end{array}$ \\
\hline $\begin{array}{l}\text { Lei Complementar } \\
\qquad n^{\circ} 200 / 15\end{array}$ & $\begin{array}{l}\text { Institui a Taxa de Credenciamento e Vistoria para Transporte de } \\
\text { Resíduos Sólidos no Município. }\end{array}$ \\
\hline Lei $n^{\circ} 10.340 / 15$ & $\begin{array}{l}\text { Altera a Lei n } 8.408 / 99 \text { para tornar mais severas as sanções } \\
\text { direcionadas aos grandes geradores de resíduos em Fortaleza. }\end{array}$ \\
\hline $\begin{array}{l}\text { Decretos } \\
\text { Municipais }\end{array}$ & Assuntos \\
\hline $\begin{array}{l}\text { Decreto } n^{\circ} \\
9.374 / 94\end{array}$ & Coleta e destinação de resíduos sólidos \\
\hline $\begin{array}{l}\text { Decreto } n^{\circ} \\
5.329 / 96\end{array}$ & Institui o Conselho Municipal de Defesa do Meio Ambiente \\
\hline $\begin{array}{l}\text { Decreto } n^{\circ} \\
10.696 / 00\end{array}$ & Diretrizes para a gestão de resíduos sólidos de Fortaleza. \\
\hline
\end{tabular}


Decreto $n^{\circ}$

$10.763 / 00$

Institui o selo sanitário e ambiental.

Fonte: Adaptado de Sanetal (2012, p. 245)

Em 1974, a Lei n 4.384 instituiu o setor de Engenharia Sanitária pertencente à Secretaria de Saúde, demonstrando o interesse municipal em lançar mão de mecanismos ambientais protetivos. Em seguida, o Código de Obras e Posturas, regulado pela Lei n 5.530/81, passou a instruir as obras públicas e privadas no município, tratando em alguns momentos da proibição de descarte de resíduos em áreas que afetariam a saúde humana e a natureza.

Em referência aos resíduos sólidos, a Lei municipal $n^{\circ} 8.408 / 99$ trata da responsabilidade quanto à manipulação de resíduos produzidos em grande quantidade. A legislação municipal considera grandes geradores de resíduos aqueles que "produzem diariamente mais de 100 litros de lixo comum, 50 litros de entulhos relacionados à construção civil ou qualquer quantidade de lixo com risco de contaminação do ambiente". ${ }^{19}$ O diploma normativo foi recentemente alterado pela Lei $n^{\circ} 10.340 / 15$ para tornar mais severas as sanções (graduadas desde leve a gravíssima) direcionadas aos maiores produtores de resíduos do município. Além da multa, o gerador ainda poderá ter as atividades suspensas ou cassadas quando necessário ao restabelecimento da normalidade ambiental.

A referida legislação municipal aponta o grande gerador como responsável pelos serviços de condicionamento, transporte e destinação final, assim como determina a responsabilidade dos fabricantes de pneumáticos e de seus derivados pela disposição final dos produtos, independentemente do peso, do volume e da origem. Ademais, por se tratar de grandes quantidades de resíduos e a possibilidade de um impacto ambiental de grandes proporções, a lei condiciona de modo exclusivo a empresas e a geradores cadastrados na atividade de coleta, armazenamento, transporte, tratamento e destinação final dos resíduos, não citando qualquer participação individual ou coletiva dos catadores no processo.

Não se deve deixar de registrar as diversas leis municipais que tratam da destinação final de resíduos. É o caso da Lei $n^{\circ} 9.357 / 08$ ao se referir à obrigação de implantar coleta seletiva nas praças de alimentação de shoppings e de supermercados em Fortaleza e da Lei $n^{\circ}$ 9.536/09 que regulamenta a reciclagem e a destinação final de eletrônicos no município, bem

\footnotetext{
${ }^{19}$ Art. $1^{\circ}$ da Lei n ${ }^{\circ} 8.408 / 99$.
} 
como a Lei n 9.947/12 que estipula o tratamento e a reciclagem de óleos e gorduras de origem vegetal, animal e uso culinário.

A Lei $n^{\circ}$ 10.190/14 versa sobre a coleta e a destinação final das embalagens plásticas vazias de óleos lubrificantes, determinando providências para um correto recolhimento do material no intuito de preservação do ambiente. O Decreto $n^{\circ} 11.260 / 02$, a seu turno, regulamenta a necessidade de colocação de recipientes para acondicionar resíduos sólidos nas vias públicas de Fortaleza, demonstrando a implementação de políticas ambientais no município.

É importante destacar, ainda, a Lei n 9.544/09 que institui a coleta seletiva de resíduos sólidos em condomínios edilícios e a sua destinação para associações e cooperativas de catadores em Fortaleza. Da mesma forma, a Resolução n 1.593/09 da Câmara dos Vereadores instaurou a separação de resíduos recicláveis na instituição e a destinação do material para organizações coletivas de catadores.

O Plano Municipal de Gestão Integrada de Resíduos Sólidos de Fortaleza (PMGIRS) foi lançado em 2012 e tem vigência de 20 anos. Uma das metas do plano é a extinção definitiva dos lixões improvisados em terrenos baldios e a inserção dos catadores, por meio da promoção de suas organizações produtivas, seguindo a mesma linha do Plano Nacional de Resíduos Sólidos. Frisa-se que o planejamento não menciona de forma efetiva como essa integração das associações/cooperativas de catadores será realizada, delegando à Secretaria Municipal de Urbanismo e Meio Ambiente (SEUMA) a responsabilidade para execução do projeto.

O PMGIRS, em suas considerações finais acerca da gestão integrada de resíduos em Fortaleza, cita a urgência da formação de associações e cooperativas de catadores estabelecendo, paralelamente, um sistema de controle técnico para aquelas já constituídas. Mostra-se assertiva a inserção das organizações produtivas de catadores no gerenciamento de resíduos no município, embora deva-se especificar como isso poderá acontecer, mormente em relação à origem dos recursos que serão utilizados na infraestrutura dos empreendimentos ao longo da vigência do plano, levando em consideração a eficiência que se espera de tais entidades na execução de seus objetivos.

A legislação municipal, portanto, se mostra insuficiente nas suas disposições acerca dos catadores e de suas organizações coletivas. O PMGIRS reconhece e cita os empreendimentos solidários dos catadores como meio indispensável para a consecução dos objetivos traçados na PNRS, tendo objetivo nitidamente inclusivo de suas organizações, sem, entretanto, fixar parâmetros integrados suficientes para oferecer melhores condições de trabalho. 


\section{Catadores de Resíduos Sólidos e Políticas Públicas Inclusivas}

Somente com o reconhecimento dos catadores como atores indispensáveis no gerenciamento de resíduos sólidos é que se tornou possível perceber a implantação de programas sociais específicos que pudessem intervir na situação de extrema exclusão social desses trabalhadores. ${ }^{20}$

A estruturação dos catadores em âmbito nacional após a formação do MNCR foi indispensável para o direcionamento de programas sociais fundados em política pública de inclusão dos catadores. Altmann (2012, p. 10) aponta a dignidade da pessoa humana e o reconhecimento estatal da catação como uma função socioambiental imprescindível para a gestão dos resíduos como causas jurídicas da inclusão dos catadores em programas sociais.

O Decreto Federal 7.404/10 firma verdadeira cláusula geral a ser observada na elaboração de políticas públicas voltadas aos catadores, in verbis:

Art. 44. As políticas públicas voltadas aos catadores de materiais reutilizáveis e recicláveis deverão observar:

I - a possibilidade de dispensa de licitação, nos termos do inciso XXVII do art. 24 da Lei no 8.666, de 21 de junho de 1993, para a contratação de cooperativas ou associações de catadores de materiais reutilizáveis e recicláveis;

II - o estímulo à capacitação, à incubação e ao fortalecimento institucional de cooperativas, bem como à pesquisa voltada para sua integração nas ações que envolvam a responsabilidade compartilhada pelo ciclo de vida dos produtos; e

III - a melhoria das condições de trabalho dos catadores.

Parágrafo único. Para o atendimento do disposto nos incisos II e III do caput, poderão ser celebrados contratos, convênios ou outros instrumentos de colaboração com pessoas jurídicas de direito público ou privado, que atuem na criação e no desenvolvimento de cooperativas ou de outras formas de associação de catadores de materiais reutilizáveis e recicláveis, observada a legislação vigente.

O desenvolvimento de políticas públicas em prol dos catadores deve conter como núcleo o favorecimento à organização coletiva de trabalho, fortalecendo empreendimentos solidários por ações que consolidem a integração dos catadores na responsabilidade compartilhada pelo ciclo vital dos produtos. É que o fortalecimento das organizações coletivas, baseado na economia solidária e na autogestão, representa um avanço na concretização da PNRS, capaz de verticalizar a produção e, consequentemente, gerar maior renda ao grupo.

\footnotetext{
20 Para Kauchakje (2007, p. 61-70) toda política pública é uma intervenção social com objetivo de coordenar os recursos do Estado para "distribuição de bens desmercadorizados" por meio da fixação de metas e planejamento governamental voltados ao interesse dos mais necessitados.
} 
Ademais, conforme o Decreto Federal 7.404/10, as políticas públicas devem possibilitar e promover a melhoria das condições de trabalho dos catadores.

A partir de 2003, órgãos ligados ao Governo Federal passaram a desenvolver programas voltados especificamente à promoção da gestão associada/cooperada dos catadores. A Fundação Nacional de Saúde (FUNASA) e o Ministério das Cidades, por exemplo, investiram na construção de centro de triagens e na aquisição de caminhões para deslocamento de resíduos (SANT'ANA; METELLO, 2016, p. 30).

O Banco Nacional de Desenvolvimento Econômico e Social (BNDES) e a Fundação Banco do Brasil aplicaram capital na construção de galpões de triagem, na aquisição de equipamentos essenciais para as atividades dos catadores e na aquisição de caminhões para o deslocamento de resíduos. O Ministério do Meio Ambiente (MMA) auxiliou mais de 400 municípios na elaboração de planos municipais e intermunicipais de gestão integrada de resíduos sólidos (SANT'ANA; METELLO, 2016, p. 30).

Ações isoladas já não comportavam as necessidades dos catadores. Foi imperioso a formulação de políticas específicas para tratar de suas peculiaridades, dispondo de maiores aportes financeiros para atender as necessidades desses trabalhadores. Assim, o Governo Federal, em parceria com a Fundação Banco do Brasil, o Ministério do Trabalho, o BNDES e a Petrobrás, lançou o Programa Cataforte com o propósito de aperfeiçoar a atuação dos empreendimentos solidários, tornando-os aptos à realização da coleta seletiva.

A elaboração do Cataforte tornou-se possível com o Decreto $n^{\circ} 7.405 / 10$ que instituiu o Programa Pró-Catador, incumbindo de promover e fortalecer a participação da organização coletiva dos catadores na cadeia da reciclagem, ampliando as oportunidades de inclusão social. O programa está atualmente na terceira etapa de implantação e já atingiu mais de 10.600 trabalhadores em 20 unidades federativas, proporcionando a formação dos catadores organizados em aspectos sociais, profissionais, políticos e culturais. Ao lado disso, o programa promove apoio técnico aos empreendimentos solidários, melhoria das condições de trabalho dos catadores e estímulo à formação de redes comerciais (NASCIMENTO et. al., 2016, p. 267).

O Decreto n 7.405/10 implantou ainda o Comitê Interministerial para Inclusão Social e Econômica dos Catadores de Materiais Reutilizáveis e Recicláveis, coordenado pela SecretariaGeral da presidência da República, com objetivo de apoiar a inclusão social dos catadores, articulando políticas setoriais, definindo o plano de ação do programa pró-catador e propondo campanhas educativas para fomentar a inclusão desses atores sociais. 
Em 2011, os catadores foram beneficiados com uma ação do Governo Federal que os inseriu na seção de inclusão produtiva do programa "Brasil sem miséria". Essa política pública tem como objetivo melhorar as condições de trabalho do grupo, ofertando curso de aperfeiçoamento profissional, ampliando a participação na coleta seletiva e concedendo-lhes uma melhor infraestrutura de trabalho (IPEA, 2013, p. 40). A despeito do aparato legal e programático com escopo de fomentar as cooperativas e as associações de catadores, a realidade aponta que cerca de $60 \%$ das organizações são de baixa ou baixíssima eficiência, constituídas por grupos desorganizados, com pouco ou nenhum equipamento de trabalho e necessidade constante de suporte financeiro (IPEA, 2013, p. 40).

Com esse exato fundamento, Slivinik, Falvo e Sato (2012, p. 110) denunciam a necessidade de uma reestruturação das cooperativas de catadores em aspectos gerenciais, financeiros e tributários para garantir a formação de empreendimentos autossustentáveis. Os autores reconhecem a importância da ajuda de entes governamentais e não governamentais na estruturação e no desenvolvimento das organizações, porém propõem uma mudança na gênese das políticas públicas, de modo a deixar o caráter assistencialista para tomar um padrão gerador de trabalho e renda. Nas conclusões dos estudos, os autores constataram que, da forma como é realizado no Brasil, o modelo cooperativista de catadores é ineficiente, pois são poucos os casos de cooperativas de manejo de resíduos que conseguem gerar renda mínima aos trabalhadores, o que as faz permanecerem de forma reiterada necessitando de suporte externo para conseguir manter um padrão, na prática, abaixo do esperado.

Ademais, para impedir o desvio de verbas públicas aplicadas em políticas para o fomento do trabalho coletivo dos catadores, faz-se necessário a utilização de critérios para atestar o "caráter autogestionário" da associação ou da cooperativa, como a exigência de quitação com as obrigações relativas ao funcionamento da organização coletiva, a realização de eleições periódicas para coordenadores dos empreendimentos e a exigência do cumprimento de regras para a gestão das atividades das organizações (IPEA, 2013, p.41).

Fortaleza lançou em 2013 o programa "reciclando atitudes" com o objetivo de promover processos sustentáveis de reciclagem com inclusão dos catadores, em parceria com a Petrobrás, Caritas, Rede de Catadores do estado do Ceará e a Fundação Banco do Brasil. O programa prevê ações de instalação de centro de triagens e auxílio na comercialização dos materiais, apoiando a gestão coletiva dos trabalhadores. Conforme a Prefeitura, "por meio do programa já foram capacitados 800 catadores para atuarem adequadamente, em especial, em 
grandes eventos, como a Copa do Mundo, na qual foram coletadas 45 toneladas de resíduos" (FORTALEZA, 2016).

A coleta dos resíduos em Fortaleza é um programa direcionado à melhoria das condições de limpeza da cidade, à educação ambiental e à sustentabilidade. Porém, sob a dimensão social, é inegável que também promove o trabalho coletivo dos catadores. Isso porque o gerenciamento do programa é realizado pela SEUMA que fomenta a gestão compartilhada dos trabalhos, já que a primeira condição para que os catadores participem da coleta seletiva é a sua integração em associações ou cooperativas, a fim de que sejam parceiros do município pela contratação direta, conforme o preceito do artigo $24, \mathrm{XXVII}$, da Lei $\mathrm{n}^{\circ}$ 8.666/93 (SANETAL, 2012, p. 30).

Ainda no que concerne ao município de Fortaleza, destaca-se ações articuladas em parcerias com entidades privadas, como ocorre com o projeto Rede CATASOL, que foi operado pela Caritas Regional e pelo Banco do Brasil, proporcionando apoio técnico às organizações coletivas no momento do contato com as indústrias recicladoras, a fim de Ihes verticalizar a produção e articular parcerias com geradores de resíduos mais expressivos (SANETAL, 2012, p. 160).

A maior parte das políticas públicas efetivamente implementadas e direcionadas aos catadores centram-se no aprimoramento da infraestrutura das organizações coletivas, com visibilidade ainda inexpressiva para o crescimento humano dos trabalhadores, como programas educativos permanentes que iniciassem com alfabetização e evoluíssem gradativamente para agregar conhecimentos substanciais sobre direitos e formação crítica.

De todo modo, resulta evidente, que o apoio estrutural às organizações de catadores mostra-se fundamental, porquanto em médio prazo eleva a qualidade econômica do empreendimento. No entanto, não se pode perder de vista ações que fomentem o desenvolvimento pleno do ser humano, levando em consideração a elaboração de políticas públicas que ampliem as suas capacidades. O Estado do Rio de Janeiro, por exemplo, aprovou a Lei $n^{\circ}$ 6.724/14 que determinou a obrigatoriedade das empresas de coleta de resíduos em vacinar contra a hepatite " $\mathrm{A}$ " todos os funcionários que trabalham na coleta do lixo, tornandose um exemplo de boas práticas de políticas públicas inclusivas que beneficiam os catadores no país.

Magalhães (2012, p. 140) destaca que os programas sociais do governo são direcionados aos catadores já organizados, não contemplando aqueles que têm atuação independente cujas condições de trabalho são ainda mais degradantes. É necessário o 
aperfeiçoamento dos programas sociais mediante a integração das políticas públicas nacionais, de modo a tornar consolidado o amparo às organizações coletivas e, ao mesmo tempo, permitir a elaboração de novas políticas especificas que possam vislumbrar o desenvolvimento pessoal do catador.

\section{CONTEXTO HISTÓRICO DA ORGANIZAÇÃO COLETIVA DE CATADORES EM FORTALEZA}

A história dos catadores de Fortaleza se inicia com as intensas migrações do interior para a capital cearense. O fenômeno migratório, intensificado na década de 1960, acontecia em grande parte motivado pelas péssimas condições de vida no interior do Estado, justificando a procura pela metrópole como refúgio capaz de proporcionar a qualidade de vida que não se podia encontrar no meio rural.

Com efeito, as migrações advieram principalmente de dois fatores: primeiro, pela ausência de políticas voltadas à zona rural para amenizar os efeitos da seca; depois, pelo arranjo político impulsionado pelos coronéis do exército Virgílio Távora, César Cals e Adauto Bezerra ao perceberem na industrialização uma estratégia para o desenvolvimento da cidade. O desenvolvimento urbano tornou-se, então, um polo atrativo para a população rural que se pôs em direção à capital (BERNAL, 2004, p. 116).

Ao chegar em Fortaleza, os retirantes depararam-se com grandes dificuldades, uma vez que a capital cearense já se encontrava em "processo de periferização" iniciado na década de 1950, passando a desenvolver atividades precárias, morando em péssimas condições e sofrendo privações de direitos (ARAÚJO; CARLEIAL, 2001, p. 1). Os migrantes acabaram encontrando na capital cearense as circunstâncias de vida precária das quais tanto fugiram quando abandonaram o espaço rural no interior do estado. A pobreza manifestou-se em seu lado mais danoso, a fome, que foi experimentada cotidianamente por muitos, o que levou a maioria dos retirantes ora à mendicância, ora à catação, deslocando-se em torno dos lixões da cidade ao seguir "a rota do lixo", alimentando-se de restos de comida (IZAIAS, 2010, p. 64).

Fortaleza contou com cinco lixões ao longo da história. O primeiro deles foi o João Lopes no bairro do Monte Castelo cujo funcionamento se deu entre os anos 1956 a 1960. Em seguida, o João Lopes foi substituído por outro na Barra do Ceará entre os anos 1961 a 1965. A seguir, no ano 1966, iniciou o funcionamento de um lixão no Antônio Bezerra, que rapidamente cedeu espaço a um localizado no Henrique Jorge entre os anos 1968 e 1977. O próximo lixão 
estava situado no Jangurussu, com uma extensão de 20 mil metros quadrados e uma altura de 42 metros, ativo entre os anos 1978 a 1998.

A descarga de resíduos a céu aberto era desativada à medida que ocorria o esgotamento do espaço que continha o armazenamento dos materiais. Após o fechamento do último lixão, o lixo de Fortaleza passou a ser enviado para o Aterro Sanitário de Caucaia (ASMOC), construído em consórcio com o município de Caucaia. A despeito disso, no local do antigo lixão do Jangurussu ainda funciona uma área de transbordo que prossegue recebendo inadequadamente parte do lixo do município por uma questão de logística. Há também galpões de coleta de materiais recicláveis na região onde trabalham catadores, representando um enorme desafio social, ambiental e de saúde pública, aparentemente, ainda sem solução.

Gonçalves (2005, p. 43) narra a existência de diversos amontoados de lixos em bairros periféricos como Santa Rosa, Quintino Cunha, Barroso e Tancredo Neves, que relembram os antigos lixões. Tais amontoados de lixo são abordados posteriormente no Plano Municipal de Gestão Integrada de Resíduos Sólidos de Fortaleza como obstáculos a serem superados nos próximos anos.

Não bastasse a própria catação ser perigosa em virtude da desproteção dos catadores, que a realizam em muitos momentos sem equipamento de proteção individual, ressalta-se que os lixões desativados do município causaram a desvalorização da região e a segregação social, prejudicando ainda mais os trabalhadores que, em parcela considerável, moram nas proximidades e acabam ficando distantes de serviços públicos essenciais, o que caracteriza uma injustiça ambiental com os catadores.

O fechamento do Lixão do Jangurussu foi tumultuado, visto que os catadores não aceitaram pacificamente a decisão unilateral do governo. A desativação causou grande impacto financeiro para as famílias que auferiam renda daquela atividade, motivando diversas manifestações e discussões. Alguns catadores voltaram a realizar a catação nas ruas da cidade enquanto outros se deslocaram para o ASMOC, seguindo, mais uma vez, a histórica rota do lixo, mas, dessa vez, impedidos de ingressar no aterro para realizar a catação.

Ao lado do antigo lixão foi construído o Complexo de Tratamento de Resíduos Sólidos (CTRS) tendo as autoridades estaduais e municipais estruturado uma usina de triagem para o trabalho dos catadores que antes frequentavam o lixão. O espaço mostrou-se insuficiente para acolher todos os trabalhadores, obrigando muitos a retornar, mais uma vez, às ruas de Fortaleza. Entretanto, o trabalho no CTRS diminuiu a renda dos catadores se comparado com o 
que obtinham no lixão, motivo pelo qual muitos relembram o lixão do Jangurussu com saudosismo (IZAIAS, 2010, p. 20).

Parte dos catadores de Fortaleza são trabalhadores autônomos que alugam pequenas carroças de deposeiros, utilizadas como transporte de carga para realizar a coleta do material reciclável e, posteriormente, prestar contas com o seu dono. Alguns são moradores de rua temporariamente exercendo a função de catador para obter alimentos, medicamentos ou drogas, diferentemente do catador de associações e cooperativas que, como regra, estão permanentemente na atividade (SANETAL, 2012, p. 33). ${ }^{21}$

Gadelha (2015, p. 79) apresenta uma linha evolutiva de formação das organizações coletivas de catadores em Fortaleza. O primeiro estágio caracteriza-se pela atuação independente dos trabalhadores nas ruas da capital, nos lixões e nos aterros. Nessa fase, há grande dificuldade na venda dos resíduos, ao mesmo tempo em que os catadores se tornam potenciais alvos dos atravessadores que compram a baixo preço seus materiais e os revendem valorizados às indústrias recicladoras. Esse grupo vulnerável que atua individualmente faz parte de trabalhadores em condições socioeconômicas ainda mais degradantes quando comparados àqueles que realizam a atividade de maneira organizada, quer porque a atuação coletiva aumenta o poder de barganha na venda dos resíduos, quer porque a economia solidária tornase uma fonte de sustento no modelo cooperativista/associativista.

A segunda etapa evolutiva é caracterizada pelo agrupamento informal de catadores com finalidade de crescer a renda do grupo, alcançada pela formulação de estratégia de venda do material coletado. Na fase posterior, os trabalhadores aglutinam-se em associações que passam a ter CNPJ e estatuto aprovado em assembleia geral. A formalização dos grupos para se tornarem associações tem como consequência a estruturação de uma rede de parceiros potencialmente maiores, que demonstram mais exigências para contratar. Por fim, passa-se para o estágio das cooperativas, quando a organização tem maior poder para comercializar os produtos coletados (GADELHA, 2015, p. 80). Em Fortaleza, há apenas uma cooperativa e diversas associações de catadores, conforme se pode observar no Quadro 5:

Quadro 5: Espécies de Organizações Coletivas de Catadores em Fortaleza

$$
\begin{gathered}
\text { Tipo de } \\
\text { organização }
\end{gathered}
$$

Nome

${ }^{21}$ Sobre o trabalho do catador de rua em Fortaleza, ver SILVA, 2017. 


\begin{tabular}{|c|c|}
\hline Cooperativa & $\begin{array}{c}\text { Cooperativa dos Catadores de materiais Recicláveis de Fortaleza e Região } \\
\text { Metropolitana - COOPMARES }\end{array}$ \\
\hline \multirow{10}{*}{$\begin{array}{l}\text { Associações } \\
\text { Formais }\end{array}$} & Associação Viva a Vida \\
\hline & Associação Ecológica dos Coletores de Mat. Recicláveis da Serrinha e \\
\hline & Adjacências - ACORES \\
\hline & Soc. Com. de Reciclagem de Lixo do Pirambú - SOCRELP \\
\hline & Associação dos Catadores do Jangurussu - ASCAJAN \\
\hline & Assoc. Cearense dos Trabalhadores e Trabalhadoras em Resíduos \\
\hline & Recicláveis - RECICLANDO \\
\hline & Associação dos Agentes Ambientais Rosa Virginia \\
\hline & Associação Maravilha \\
\hline & Associação dos Catadores do Serviluz - BRISAMAR \\
\hline \multirow{5}{*}{ Grupos informais } & Raio de Sol - Genibaú \\
\hline & Moura Brasil \\
\hline & Grupo de Catadores do Jardim Iracema - UCAJIR \\
\hline & Grupo de Catadores da Rosalina \\
\hline & Grupo do Quintino Cunha \\
\hline
\end{tabular}

Fonte: Adaptado de Gadelha (2015, p. 24).

Dentre os obstáculos enfrentados pelas organizações de catadores estão a descontinuidade de políticas públicas em Fortaleza; o amadorismo na gestão dos empreendimentos; a baixa remuneração dos associados/cooperados (abaixo do salário mínimo); e a quantidade insuficiente de resíduos disponíveis para a coleta. No que se refere, por exemplo, à triagem residencial de resíduos no município, quando essa é realizada, é muitas vezes feita de modo incorreto pelos fortalezenses, impedindo as associações/cooperativa de aproveitarem 40\% das 6.000 toneladas recolhidas diariamente no município, ocasionando maior quantidade de rejeitos nos aterros sanitários e matéria prima insuficiente para as associações e cooperativas (FROTA, 2014, p. 111).

Apoio indispensável na sustentabilidade dos grupos ainda em estruturação foi a fundação da Rede de Catadores do Ceará constituída 2007 como associação civil de direito privado com objetivo de desenvolver ações conjuntas entre associações, cooperativas e grupos informais de catadores em Fortaleza, bem como em sua região metropolitana. Morais e Gonçalves (2015, p. 214) destacam que a atuação da Rede de catadores do Ceará fortaleceu a 
categoria, atraiu políticas públicas municipais, ampliou a gestão democrática dos empreendimentos e aperfeiçoou a qualidade de vida dos trabalhadores. A seguir, serão analisadas as duas organizações coletivas de catadores do município de Fortaleza que foram objeto de estudo dessa pesquisa.

\section{ORGANIZAÇÕES COLETIVAS DE CATADORES EM FORTALEZA}

Associação é a união voluntária de pessoas, sem direitos e obrigações recíprocos, para finalidade não lucrativa. ${ }^{22}$ Já cooperativa é uma sociedade de pessoas que se unem voluntariamente na busca pela satisfação de objetivos comuns, desenvolvendo atividades de produção, consumo e comercialização para os cooperados. ${ }^{23}$ Os dois empreendimentos coletivos destacam-se pela adesão voluntária, gestão democrática e participativa. Outrossim, revelam-se autônomas, ainda quando recebem aportes externos de natureza pública ou privada, devendo o controle permanecer com seus sócios. O princípio do interesse pela comunidade deve estar presente em suas ações, de modo a buscar o desenvolvimento sustentável das comunidades locais (CARDOSO; CARNEIRO; RODRIGUES, 2014, p. 21).

Destaca-se a finalidade lícita dos empreendimentos, vedada qualquer associação paramilitar, ao mesmo tempo em que não desenvolvem atividade centrada no lucro, embora executem ações econômicas para atingir suas finalidades ${ }^{24}$. A seguir, passa-se à analise quanto às condições de trabalho dos catadores em uma associação e em uma cooperativa em Fortaleza.

\section{Condições de Trabalho nas Organizações Coletivas}

Na pesquisa realizada (entrevistas e observação), foram examinadas as condições de trabalhos dos catadores associados, referentes à saúde, à segurança, a direitos trabalhistas e

\footnotetext{
${ }^{22}$ Art. 53 do $\mathrm{CC} / 02$.

${ }^{23}$ A legislação infraconstitucional a dar fundamento às associações é o Código Civil, enquanto as cooperativas são regidas pela Lei $n^{\circ} 5.764 / 71$ e pelo Código Civil. A Lei n 5.764/71, cuja vigência se deu no período dos Atos Institucionais no regime militar, contém dispositivos bastante interventivos no funcionamento das cooperativas, motivo pelo qual foi somente parcialmente recepcionada pela Constituição Federal de 1988. A Cooperativa de Trabalho conta ainda com legislação especial, a Lei $n^{\circ}$ $12.690 / 12$.

${ }^{24}$ Centro de Estudos Judiciários do Conselho da Justiça Federal. Enunciado $n^{\circ} 534$ da VI Jornada de Direito Civil assenta que a associação poderá desenvolver atividade econômica, desde que não haja finalidade lucrativa
} 
previdenciários básicos como descanso, vínculo com o INSS e remuneração mensal. Ademais, a pesquisa analisou o estatuto das organizações e entrevistou os gestores. As organizações coletivas estudadas são chamadas de Associação e Cooperativa. O objetivo não é o de comparar as duas organizações, mas sim de explorar as condições de trabalho em duas organizações com estruturas, ao menos jurídicas, distintas. A associação conta com 70 membros - 50 homens e 30 mulheres -, enquanto a cooperativa conta com 30 membros - 7 homens e 23 mulheres. Quanto à forma de aquisição dos materiais, nas duas organizações os materiais são produto de doações no galpão e coleta com caminhão próprio.

A primeira organização examinada, a associação, foi constituída como uma associação civil sem fins lucrativos em 2008, com foro no Município de Fortaleza. Conforme seu estatuto, a finalidade da associação corresponde à defesa e auxílio aos catadores, favorecendo sua organização, união e respeito no desempenho das atividades de separação de resíduos. O estatuto garante, ainda, a representação judicial e extrajudicial, assim como os serviços de assessoria jurídica. ${ }^{25}$

A associação se sustenta a partir de doações no galpão e da coleta com caminhões cedidos pela prefeitura. Convém mencionar que o fato de ter sido criada ao lado de um antigo lixão favoreceu a logística do trabalho dessa associação, ao facilitar a organização de uma rede de doadores de resíduos. ${ }^{26} \mathrm{O}$ empreendimento tem uma rede de parceiros bem estruturada como condomínios, empresas e, inclusive, os Correios. A associação possui um centro de triagens em um shopping da cidade de Fortaleza e em supermercados, aumentando, portanto, o volume da produção. Destaca-se, ainda, o convênio com a SEUMA para aquisição de banners apreendidos, oriundos da poluição visual no município, encontrados logo na entrada da associação, posteriormente desmontados e vendidos, tendo em sua composição materiais mais caros, como o ferro e o aço.

O galpão onde os catadores da associação trabalham foi construído com a ajuda financeira do Banco do Brasil. O local é quente e os trabalhadores laboram na triagem dos resíduos integralmente em pé, em sua maior parte sem uso de equipamentos de proteção individual, tornando as condições de trabalho insalubres e perigosas. Parte dos associados,

\footnotetext{
${ }^{25}$ Embora a permissão para representar os associados seja de ordem constitucional e esteja presente no estatuto, o STF firmou entendimento de que não basta a permissão estatutária genérica, sendo necessária a permissão por ato individual ou por assembleia geral dos associados (BRASIL, Supremo Tribunal Federal. RE 573.232, Rel. Min. Marco Aurélio, Tribunal Pleno, julgado em 15/05/2014).

${ }^{26} \mathrm{~A}$ associação localiza-se em uma estrutura física onde continua o depósito inadequado de parte do lixo municipal. Há uma grande vala onde catadores contratados por particulares atuam em condições ainda mais precárias que os associados.
} 
especialmente os mais idosos, atuaram no antigo lixão e relataram não utilizar luvas e botas, por já terem enfrentado circunstâncias mais gravosas e não se acostumarem ao uso dos instrumentos de segurança. Outros afirmaram incomodar-se com o uso dos equipamentos protetivos por diminuírem o contato direto com o material.

$\mathrm{Na}$ eventualidade de doenças ocasionais que ensejem faltas, os associados somente auferem a remuneração do dia se apresentarem atestado médico comprovando o impedimento ao trabalho. Nos relatos, houve queixas pontuais relacionadas a pequenos cortes da pele durante o serviço. Em casos como esses, os catadores acidentados não deram importância ao corte e prosseguiram no serviço. Questionados acerca da possibilidade de acidentes mais graves, os trabalhadores responderam que o deslocamento ao centro médico seria por conta própria, não havendo amparo no seio da organização. Diante de uma impossibilidade estendida de retorno ao trabalho, passam a depender do consenso da associação para receber sua remuneração, mostrando a inconsistência do método.

Nenhum associado contribui para a previdência, seguindo o padrão nacional de baixa adesão. ${ }^{27}$ Parte dos catadores recebe ou reside com alguém que ganhe benefícios governamentais como o bolsa família, o que aponta a carência dos catadores ou de seus familiares. Com relação aos rendimentos, importante destacar que os associados recebem conforme a produção. Isso posto, destaca-se que a média remuneratória auferida a cada mês pelos trabalhadores da associação não atinge o salário mínimo (média de $R \$ 440,00$ ) mesmo nos meses em que a produção se eleva.

Uma questão merece reflexão mais acurada no ponto que diz respeito aos ganhos auferidos na associação. Isso porque aquilo que eventualmente foi alcançado pertence ao empreendimento solidário e deve ser destinado à atividade fim, não podendo ser revertido a seus membros. Como uma associação, a associação não poderia remunerar os associados, o que demonstra um procedimento incompatível com a lei. No caso, a associação funciona como cooperativa de trabalho, que tem natureza jurídica diversa, não se confundindo com aquela espécie de organização que tem legislação própria e consequências particulares no mundo jurídico. Os catadores buscam, na verdade, atividade de essência estritamente comercial e econômica, visando a repartição de sobras entre si, o que não se coaduna com o que pretende uma associação.

\footnotetext{
${ }^{27}$ A média nacional de adesão à previdência pelos catadores é de $15,4 \%$, enquanto no Nordeste é de 6,2\% (IPEA, 2013, p. 45).
}

Revista de Direito da Cidade, vol. 10, no 4. ISSN 2317-7721 pp. 2947-2987 
Com relação à jornada de trabalho e repouso, verificou-se que a maioria dos associados trabalha unicamente na associação durante oito horas por dia, de segunda a sexta-feira, com intervalo para refeição. Ocasionalmente, dedicam-se (mulheres) a serviços de limpeza geral aos fins de semana. Em quase todos os relatos, percebeu-se o contentamento em fazer parte dos quadros da associação, pois no desempenho da atividade não estão subordinados a ninguém, o que foi relatado pelos participantes como vantagem. Poucos associados manifestaram interesse em sair do empreendimento, geralmente os mais jovens em razão da baixa remuneração. Percebe-se, ainda, de modo geral, satisfação com os auxílios concedidos pela prefeitura de Fortaleza, como a concessão do caminhão para a coleta.

Os catadores passam grande parte do tempo juntos, motivo pelo qual é possível perceber afeto mútuo, relatado como um dos fundamentos para permanência como associados. Afirmações do tipo "aqui somos como uma família" foram muito comuns nas entrevistas. Esse fator associado à habilidade única centrada na catação, tida como identidade profissional, explicam a resiliência dos trabalhadores em enfrentar tanta austeridade no ambiente de trabalho.

O nível de escolaridade dos membros do grupo é baixo. Muitos sabem apenas assinar o nome, com pouca desenvoltura para a escrita e a leitura. Frota (2014, p. 84) afirmou que $14,53 \%$ dos catadores da associação são analfabetos, enquanto quase $71 \%$ têm o ensino fundamental incompleto, 8,55\% com ensino fundamental completo e apenas 5,8\% com ensino médio.

A segunda organização examinada, a cooperativa, obteve aprovação de seu estatuto social em Assembleia Geral realizada em 2012, tendo foro na comarca de Fortaleza, com atuação em todo o Estado. Na definição de seu objeto, fixa-se a prestação de serviços relacionados à coleta seletiva, à reciclagem e à recuperação de materiais recicláveis pelos cooperados. Os resíduos serão recebidos da coleta pública, privada ou de catadores individuais.

A cooperativa funciona em um formato peculiar, pois, no desempenho de suas finalidades o empreendimento solidário recebe auxílio de catadores associados, sendo considerada por seus gestores uma "cooperativa mista". Por isso, os 30 cooperados que nela existem representam sua própria instituição (associação de onde vieram). Nas visitas, percebeuse diversos catadores oriundos de um grupo informal, cuja sede localiza-se próximo à cooperativa, estando todos os associados com uniformes de seu respectivo empreendimento.

Além dos materiais tradicionalmente coletados, como papéis e plásticos, a cooperativa trabalha em convênio com a Petrobrás para o reaproveitamento do óleo destinado à produção 
de biodiesel. Vale destacar também que os cooperados recebem ensinamentos acerca de resíduos eletrônicos. Destarte, regularmente são capacitados para o desmonte de computadores e o aproveitamento de peças, o que possivelmente aumentará a renda dos cooperados, uma vez que a previsão é de que nos próximos anos haja um crescimento considerável dessa espécie de resíduos, reconhecidamente de valor mais alto.

Os catadores da cooperativa trabalham em galpão cedido pela prefeitura, que também doou o caminhão responsável pelo transporte dos resíduos. A jornada é de 8 horas por dia, de segunda a sexta, com intervalo para alimentação e descanso. Destaca-se que eventualmente há trabalho aos sábados quando ocorrer demanda extraordinária. Os catadores recebem equipamentos de proteção individual, mas geralmente se incomodam com o uso, pois as luvas são rígidas, prejudicando o contato com os materiais. Esse fator torna o trabalho perigoso, situação acentuada pelo ambiente quente e abafado. Com o uniforme constantemente suado, os catadores fazem a triagem dos materiais e a purificação do óleo para auferirem uma renda média de R\$ 600 reais por mês.

Logo, mesmo a única cooperativa de catadores em Fortaleza não atinge o salário mínimo na distribuição de sobras aos cooperados. A lei do cooperativismo (Lei n 12.690/12), em seu artigo $7^{\circ}$, assegura uma série de direitos sociais aos cooperados, ${ }^{28}$ que dificilmente podem ser efetivados no seu conjunto pelas cooperativas de catadores dadas as condições financeiras e estruturais dessas. A inviabilidade econômica no que concerne à garantia de um trabalho decente não se restringe às cooperativas, estendendo-se às associações de catadores.

Igualmente aos catadores associados, os cooperados não recebem em faltas ocasionais, a não ser que demonstrem por atestado que o impedimento se deu por motivo de saúde. 0 nível de escolaridade é baixo. Dentre os participantes, apenas uma jovem completou o ensino médio, apresentando os demais dificuldades para leitura e escrita. Uma vez por semana os cooperados frequentam um curso de artesanato em salas localizadas no próprio galpão, procurando alternar o trabalho com atividades diversas.

Deve-se destacar que tal qual a associação, a cooperativa também conta com uma gestão insuficiente, dispondo de apenas um profissional, o contador, para fiscalização das

\footnotetext{
${ }^{28}$ São os seguintes os direitos do cooperado: piso da categoria, duração do trabalho normal não superior a 8 (oito) horas diárias e 44 (quarenta e quatro) horas semanais, repouso semanal remunerado, preferencialmente aos domingos; repouso anual remunerado; retirada para o trabalho noturno superior à do diurno; adicional sobre a retirada para as atividades insalubres ou perigosas; seguro de acidente de trabalho.
} 
contas, não alcançando o cumprimento da maior parte dos direitos que oferece em seu estatuto, como serviço de apoio jurídico aos interesses dos trabalhadores.

Mesmo em ambiente de intensa convivência durante as horas de serviço, foi possível colher informações acerca de desentendimentos advindos de acusações mútuas de trabalho ineficiente, posto que a soma da produtividade influencia na repartição de sobras, o que os põem em constante atrito. Apesar disso, os trabalhadores mostraram-se satisfeitos de pertencerem à cooperativa, demonstrando contentamento pela intervenção da prefeitura ao disponibilizar o galpão e o caminhão para a coleta dos materiais.

Constatou-se na entrevista com a gestora da cooperativa que os principais desafios do empreendimento são a tributação que encarece a operação, trazendo perda em escala nas sobras a serem distribuídas entre os cooperados, e baixo valor dos recicláveis.

Grande parte das dificuldades encontradas nas organizações de catadores de Fortaleza são compartilhadas pelos demais empreendimentos solidários no Brasil, merecendo apontamentos e análise de resultados acerca das impressões e possível reversão desse quadro.

\section{Análise e Discussão de Resultados}

As condições das organizações coletivas de catadores analisadas não se distanciam do padrão nacional, já que ambas apresentam eficiência média, ou seja, já estão formalizadas, contam com apoio financeiro de diversas entidades, possuem alguns equipamentos essenciais para o manejo dos resíduos, e os próprios membros da organização são destinatários imediatos da renda mensal auferida com a produção.

Apesar de serem organizações bem-sucedidas, considerando-se o seu tempo de existência e a rede de parceiros, ainda assim as dificuldades são significativas. Por exemplo, a gestão das organizações carece de profissionais no desempenho das atividades de administração e contabilidade. No que concerne às condições de trabalho, não há diferenças significativas entre os catadores associados e os cooperados. Em ambos os casos, os trabalhadores exercem sua atividade em um patamar inferior a de um trabalho decente: remuneração abaixo de um salário mínimo para uma jornada completa, sem garantia de descansos remunerados, ambiente de trabalho insalubre e vulneráveis a acidentes e doenças no trabalho. Embora sejam trabalhadores autônomos, ou seja não alcançados pelo direito do trabalho, a própria legislação disciplinadora das cooperativas de trabalho (Lei $n^{\circ}$ 12.690/12) garante direitos consistentes cuja implementação poderia, em tese, retirar os catadores 
cooperados de uma situação de violação imediata a seus direitos. Na prática, porém, a cooperativa não apresenta condições econômicas de implementar os direitos garantidos em lei, apesar de apresentar um projeto que visa o pagamento do INSS de uma pequena parte dos catadores.

A despeito de se poder afirmar que as condições de trabalho nos empreendimentos analisados tenham progredido em relação à catação realizada de forma individual nos lixões e nas ruas, o ganho nesse aspecto não pode ser plenamente comemorado, pois a melhoria se deve ao fato de o trabalho no lixão e na rua ser extremamente danoso, com exposição permanente ao sol, sujeição a atropelamentos e a cortes. Isso não significa que as atuais circunstâncias sejam satisfatórias, dado que os catadores permanecem em atividade insalubre e perigosa realizada sem equipamentos de proteção, trabalhando na maior parte da jornada em pé, sem qualquer seguro contra acidente de trabalho.

A política de inclusão dos catadores via suas organizações coletivas pela legislação ambiental sem a garantia de um trabalho digno e seguro parece ser insuficiente para alterar a situação de exploração de um trabalhador vulnerável a violações de sua integridade. Essa política, apesar de representar um avanço, não pode ser a medida única para desprecarizar o trabalho do catador de resíduos. A estratégia de que a organização coletiva e a participação no sistema de gerenciamento dos resíduos irão resultar em uma organização com condições de trabalho dignas não parece se concretizar. Por ser um grupo de trabalhadores extremamente vulneráveis, há a necessidade de suportes administrativos, financeiros, tecnológicos por parte do Estado e de outras entidades que permitam a plena inclusão do catador. Esse tipo de suporte deve ser associado à responsabilização de quem se beneficia do trabalho dos catadores, mormente prefeituras e grandes geradores de resíduos. Não há que se admitir que os catadores em condições de trabalho degradantes realizem uma atividade de extrema importância ambiental às margens do Estado.

Os catadores, nas duas organizações coletivas analisadas, não são remunerados pelo serviço ambiental prestado. Nesses casos, indubitavelmente há um interesse estatal de utilizar o trabalho precário, sem preocupação ou responsabilização pelas condições de trabalho e tampouco pelo cumprimento de direito fundamentais. Qualquer política pública ou estratégia regulatória que não enfrente essa questão terá caráter meramente assistencialista, de modo a perpetuar a exploração do trabalho dos catadores.

A adoção da Política Nacional de Resíduos Sólidos representou um desenvolvimento positivo para a situação laboral de catadores, como os da associação e da cooperativa. A Lei $n^{\circ}$ 
12.305/10 é um marco, não apenas para a gestão de resíduos sólidos, mas também para a integração dos trabalhadores nesse processo. No entanto, há que se realizar uma projeção dentro de um cenário atual cuja perspectiva prática mostra-se inteiramente incongruente com a dignidade humana. Isso porque, ao se estudar as organizações coletivas mais bem-sucedidas de Fortaleza, conclui-se que mesmo essas não consegue alcançar o salário mínimo como renda mensal aos cooperados/associados e não asseguram o cumprimento de direitos trabalhistas básicos dos seus associados.

Não há dentro dos empreendimentos condições de trabalho adequadas à segurança, tampouco políticas públicas capazes de amparar de maneira integrada e não ocasional os catadores. Nenhum projeto pode mostrar-se juridicamente aceitável quando se ferem valores constitucionais, ainda que se transmita de modo aparente uma faceta social inclusiva, embora na prática se mostre danoso à vida e à saúde dos trabalhadores.

\section{CONCLUSÃO}

Os catadores de resíduos sólidos realizam uma atividade de inegável valor ambiental. No entanto, esse trabalho é realizado em condições de extrema precariedade e vulnerabilidade. A solução oferecida pelo direito a esse problema vem na forma da política de inclusão dos catadores nos sistemas de gestão de resíduos via suas organizações coletivas - associações e cooperativas. A política de inclusão é prevista na Política de Resíduos Sólidos no âmbito federal, estaduais e municipais. A estratégia é a de que organizados coletivamente os catadores poderão, de forma autônoma, fortalecer economicamente sua atividade e, consequentemente, melhorar suas condições de vida e trabalho. A política de inclusão prevê ainda possíveis fomentos econômicos a essas associações e o pagamento pelos serviços ambientais prestados medidas que ainda não se concretizaram na maioria das cidades brasileiras.

O objetivo desta pesquisa foi o exatamente o de refletir se a política de inclusão é uma estratégia adequada para atacar a precariedade e vulnerabilidade que cercam o trabalho dos catadores de resíduos.

Tomando como exemplo uma associação e uma cooperativa na cidade de Fortaleza, este estudo observou que em ambas o trabalho é realizado em condições abaixo do patamar de um trabalho decente - ausência de equipamentos de proteção à saúde e segurança dos trabalhadores, remuneração abaixo do salário mínimo, incerteza no que concerne ao direito ao repouso e férias, por exemplo. A análise desenvolvida sugere que a política de inclusão é uma 
medida insuficiente para garantir condições de trabalho decente. A ausência de políticas públicas ou a permanência de políticas inconsistentes aparenta dar suporte a um cenário de aproveitamento do trabalho barato e ao mesmo tempo danoso à saúde e à vida dos catadores. As políticas públicas devem enfrentar a complexa questão da responsabilização daqueles que se beneficiam do trabalho dos catadores - em especial, o poder público e os grandes geradores de resíduos - pelas condições de trabalho nas quais essa atividade é exercida. A reflexão jurídica deve, portanto, considerar os meios para que essa responsabilidade seja cumprida.

\section{REFERÊNCIAS}

ALTMANN, A. Pagamento por Serviços Ambientais Urbanos como instrumento de incentivo para os catadores de materiais recicláveis no Brasil. 2012. Disponível em:<http://www.planetaverde.org/mudancasclimaticas/index.php?ling=por\&cont=artigos $>$. Acesso em: 01 jul. 2016.

ARAÚJO, S. M. V. G.; JURAS, I. A. G. M. Comentários à lei dos resíduos sólidos: Lei no 12.305. São Paulo: Saraiva, 2011.

BERNAL, M. C. C. A metrópole emergente: a ação da capital imobiliária na estruturação urbana de Fortaleza. Fortaleza: UFC, 2004.

BRASIL. Código Civil. Brasília, DF, Congresso Nacional, 2002.

BRASIL. Constituição (1988). Constituição da República Federativa do Brasil. Brasília, DF, Congresso Nacional, 1988.

BRASIL. Decreto n 50.877/61.Brasília, DF, Presidência da República, 1961.

BRASIL. Decreto n 76.389/75 Brasília, DF, Presidência da República, 1975.

BRASIL. Decreto n 86.028/81. Brasília, DF, Presidência da República, 1981.

BRASIL Decreto n 875/93. Brasília, DF, Presidência da República, 1993 
BRASIL Decreto n 1.306/94. Brasília, DF, Presidência da República, 1994.

BRASIL Decreto n 3.179/99. Brasília, DF, Presidência da República, 1999

BRASIL. Decreto n 5.940/06. Brasília, DF, Presidência da República, 2006.

BRASIL. Decreto n 7.217/10. Brasília, DF, Presidência da República, 2010a.

BRASIL. Decreto n 7.404/10. Brasília, DF, Presidência da República, 2010b.

BRASIL. Decreto n 7.405/10. Brasília, DF, Presidência da República, 2010c.

BRASIL. Lei n 5.318. Brasília, DF, Congresso Nacional, 1967.

BRASIL. Lei n 5.764/71. Brasília, DF, Congresso Nacional, 1971.

BRASIL. Lei n 7.347. Brasília, DF, Congresso Nacional, 1985.

BRASIL. Lei n 7.797. Brasília, DF, Congresso Nacional, 1989a.

BRASIL. Lei n 7.802. Brasília, DF, Congresso Nacional, 1989b.

BRASIL. Lei n 9.008/95. Brasília, DF, Congresso Nacional, 1995.

BRASIL. Lei n 9.605/98. Brasília, DF, Congresso Nacional, 1998.

BRASIL. Lei n 10.257/01 Brasília, DF, Congresso Nacional, 2001.

BRASIL. Lei n 11.445/07. Brasília, DF, Congresso Nacional, 2007

BRASIL. Lei n 12.305/10. Brasília, DF, Congresso Nacional, 2010. 
BRASIL, Supremo Tribunal Federal. HC 106.808, Segunda Turma, Rel. Min. Gilmar Mendes, julgamento em 9-4-2013.

BRASIL, Supremo Tribunal Federal. ADPF 347 MC/DF, Rel. Min. Marco Aurélio, Tribunal Pleno, julgado em 09/09/2015.

ARAÚJO, A. M. M; CARLEIAL, A. N. O processo de metropolização em Fortaleza: uma interpretação pela migração. Scripta Nova: Revista Electrónica de Geografía y Ciencias Sociales, n. 5, 2001.

CARDOSO, U. C.; CARNeIRO, V. L.; RODRIGUES, E. R. Q. R. Associações - Séries empreendimentos solidários. Brasília: SEBRAE, 2014.

CEARÁ. Decreto n 26.604/02. Governadoria do Estado, 2002.

CEARÁ. Decreto n²9.306/08. Governadoria do Estado, 2008.

CEARÁ. Lei n 11.411/87. Assembleia Legislativa. Fortaleza- CE, 1987.

CEARÁ. Lei n 11.423/88. Assembleia Legislativa. Fortaleza- CE, 1988.

CEARÁ. Lei nº 12.225/93. Assembleia Legislativa. Fortaleza- CE, 1993.

CEARÁ. Lei n 12.944/99. Assembleia Legislativa. Fortaleza- CE, 1999.

CEARÁ. Lei n 13.304/03. Assembleia Legislativa. Fortaleza- CE, 2003.

CEARÁ. Lei nº 14.198/08. Assembleia Legislativa. Fortaleza- CE, 2008.

CEARÁ. Lei nº 14.401/09. Assembleia Legislativa. Fortaleza- CE, 2009.

CEARÁ. Lei n 14.892/11. Assembleia Legislativa. Fortaleza- CE, 2011a. 
CEARÁ. Lei n 15.086/11. Assembleia Legislativa. Fortaleza- CE, 2011b.

CEARÁ. Lei n 15.093/11. Assembleia Legislativa. Fortaleza- CE, 2011c.

CEARÁ. Lei n¹3.103/01. Assembleia Legislativa. Fortaleza- CE, 2001.

FORTALEZA, Lei n 4.384/74. Câmara Municipal, 1974.

FORTALEZA, Lei n5.530/81. Câmara Municipal, 1981.

FORTALEZA. Decreto n 10.696/00. Prefeitura Municipal, 2000a.

FORTALEZA. Decreto n 10.763/00. Prefeitura Municipal, 2000b.

FORTALEZA. Decreto n 5.329/96. Prefeitura Municipal, 1996a.

FORTALEZA. Decreto n 9.374/94. Prefeitura Municipal, 1994.

FORTALEZA. Lei Complementar 062/09. Câmara Municipal, 2009.

FORTALEZA. Lei Complementar n²00/15. Câmara Municipal, 2015.

FORTALEZA. Lei nº 10.006/13. Câmara Municipal, 2013.

FORTALEZA. Lei n 10.183/14. Câmara Municipal, 2014a.

FORTALEZA. Lei n 10.190/14. Câmara Municipal, 2014b.

FORTALEZA. Lei n 10.204/14. Câmara Municipal, 2014c.

FORTALEZA. Lei n 10.340/15. Câmara Municipal, 2015.

FORTALEZA. Lei nº 6.271/88. Câmara Municipal, 1988a. 
FORTALEZA. Lei n 7.061/92. Câmara Municipal, 1992.

FORTALEZA. Lei n 7.987/96. Câmara Municipal, 1996b.

FORTALEZA. Lei n 8.236/98. Câmara Municipal, 1998b.

FORTALEZA. Lei n 8.287/99. Câmara Municipal, 1999a.

FORTALEZA. Lei n 8.408/99. Câmara Municipal, 1999b.

FORTALEZA. Lei n 8.621/02. Câmara Municipal, 2002a.

FORTALEZA. Lei nº 8.621/02. Câmara Municipal, 2002b.

FORTALEZA. Lei n 8.869/04. Câmara Municipal, 2004a.

FORTALEZA. Lei n 8.904/04. Câmara Municipal, 2004b.

FORTALEZA. Lei n 9.312/07. Câmara Municipal, 2007.

FORTALEZA. Lei n 9.357/08. Câmara Municipal, 2008.

FORTALEZA. Lei n 9.506/09. Câmara Municipal, 2009a.

FORTALEZA. Lei n 9.536/09. Câmara Municipal, 2009b.

FORTALEZA. Lei n 9.927/12. Câmara Municipal, 2012a.

FORTALEZA. Lei n 9.947/12. Câmara Municipal, 2012b.

FORTALEZA. PREFEITURA DE FORTALEZA. . Canal Urbanismo e Meio Ambiente: Reciclando Atitudes. 2016. Disponível em: <http://urbanismo.fortaleza.ce.gov.br/urbanismo-e-meioambiente/206-programa-reciclando-atitudes>. Acesso em: 25 ago. 2016. 
FROTA, A. J. Coleta seletiva na cidade de Fortaleza- Ce: Desafios e perspectivas de sustentabilidade nas associações de catadores de resíduos sólidos. 2014. 164f. Dissertação (Mestrado em Administração de Empresas), UNIFOR, Fortaleza, 2014.

GADELHA, P. M. B. Gestão das organizações de resíduos sólidos sob a ótica da economia solidária. 2015. 150f. Dissertação (Mestrado em Logística e Pesquisa Operacional). Universidade Federal do Ceará. Fortaleza, 2015.

GONÇALVES, R. C. M. A voz dos catadores de lixo em sua luta pela sobrevivência. 2005. Dissertação (Mestrado em Políticas Públicas e Sociedade) - Universidade Estadual do Ceará, UECE, 2005.

INSTITUTO DE PESQUISA ECONÔMICA APLICADA- IPEA. Situação social das catadoras e dos catadores de material reciclável e reutilizável - Brasil. Brasília: IPEA, 2013.

IZAIAS, F. M. C. Na rota do lixo: percursos de vida e trabalho de catadores do complexo de tratamento de resíduos sólidos do Jangurussu. 2010. 151f. Dissertação (Mestrado em Sociologia) - Programa de Pós-graduação em Sociologia, Universidade Federal do Ceará, Fortaleza, 2010.

KAUCHAKJE, S. Gestão pública de serviços sociais. Curitiba: IBPEX, 2007.

MAGALHÃES, B.J. Liminaridade e Exclusão: os catadores de materiais recicláveis e suas relações com a sociedade brasileira. 2012. Dissertação (Mestrado em Antropologia). - Programa de Pósgraduação em Antropologia, Faculdade de Filosofia e Ciências Universidade Federal de Minas Gerais, Belo Horizonte, 2012.

NASCIMENTO, A.S.; JUNIOR, J. O. C.; FERREIRA, M. A.; SILVA, R. B. Logística solidária para inclusão social e produtiva de catadores e catadoras: a experiência do Cataforte II. In: Pereira; Goes (org.). Catadores de Materiais Recicláveis um Encontro Nacional. Rio de Janeiro. Mapas color, 2016.

RIO DE JANEIRO, Lei n 6.724/14. Assembleia Legislativa, 2014. 
SANETAL - PREFEITURA MUNICIPAL DE FORTALEZA. Plano municipal de gestão integrada de resíduos sólidos de Fortaleza. 2012. Disponível em: <http://www.progere.ufc.br/wpcontent/uploads/2015/08/Plano-Municipal-de-Gest\%C3\%A3o-Integrada-de-Res\%C3\%ADduosS\%C3\%B3lidos-de-Fortaleza.pdf>. Acesso em: 18 jun. 2016.

SANT'ANA, D.; METELLO, D. Reciclagem e inclusão social no Brasil: Balanço e desafios. In: Pereira; Goes (org.). Catadores de Materiais Recicláveis um encontro nacional. Rio de Janeiro: Mapas Color, 2016.

SILVA, Ana Patrícia Pereira da. Situação Social de Catadores de Materiais Reutilizáveis e Recicláveis que Trabalham no Centro de Fortaleza-CE. Instituto Federal de Educação, Ciência e Tecnologia - UFC, Dissertação de Mestrado, 2017.

SLIVINIK, A.; FALVO, J. F.; SATO, N. K. Cooperativas de manejo de resíduos sólidos urbanos: apontamentos para uma política de geração de trabalho e de renda. Revista da ABET. v. 11, n. 1, p. 98-113, 2012.

Trabalho enviado em 09 de agosto de 2018

Aceito em 06 de janeiro de 2018 